\title{
THE DAVID BRUCE LABORATORIES 25th ANNIVERSARY
}

\author{
Lieutenant-Colonel J. E. NOBLE, * \\ M.C.Path., M.R.C.S., L.R.C.P., D.T.M. \& H., R.A.M.C.
}

The David Bruce Laboratories

\section{Introduction}

Twenty five years ago, beginning on 1st April and completed by 25 th July, 1942, The David Bruce Laboratories in their present form were brought together at the Manor House in the small Wiltshire village of East Everleigh.

We who are associated with the unit are frequently asked such questions as "What are the David Bruce Laboratories ", "What do they do ?", "What is their history ?", and "Who was David Bruce?".

The 25th anniversary of the unit in its present form and at its present location affords us the opportunity of answering these questions. Furthermore, as the unit and the Manor House in which it is housed are not themselves without interest, it is hoped that we may also make a useful if small contribution to the history of the Royal Army Medical Corps.

\section{David Bruce}

So much has been written on and by David Bruce that, in answer to "Who was he ?", only the most condensed summary of his career can be included here.

Major-General Sir David Bruce, K.C.B., M.B., D.Sc., F.R.C.P., F.R.S., was born on 29th May, 1855, in Melbourne, Australia, the son of a gold miner. Brought home to Scotland at the age of five, he was educated in Stirling, and then worked as a warehouseman in Manchester before entering Edinburgh University to study medicine. He graduated Bachelor of Medicine and Master of Surgery in 1881, and entered general practice in Reigate. Here he met and in 1881 married Mary Elizabeth Steele, daughter of the retired senior partner of the practice with which Bruce was associated.

Disliking general practice, he joined the Army in 1883 and gained first place in the entrance examination and first place in the passing out examination at the Army Medical School in his first year. From 1884 to 1888 he served in Malta and Egypt where he not only discovered the causative organism of Malta fever (since 1920 named Brucella melitensis in his honour) but earned official thanks for his investigations into a cholera epidemic.

He then spent a year studying bacteriology under Koch in Berlin, followed by a tour as Assistant. Professor of Pathology at Netley, at first under Sir William Aitkin and later with Sir Almroth Wright.

In 1894 Bruce went to South Africa and took part in the defence of Ladysmith. During this tour he demonstrated that nagana, a disease of cattle, was due to a trypanosome, (T. brucei) conveyed by the bite of the tsetse fly. This was the first occasion upon which carriage of a causative organism of disease by an insect vector had been proved. Much of his later work was present in investigating other forms of trypanosomiasis.

*Now Eastern Command Laboratory, The Queen Alexandra Military Hospital, Millbank. 


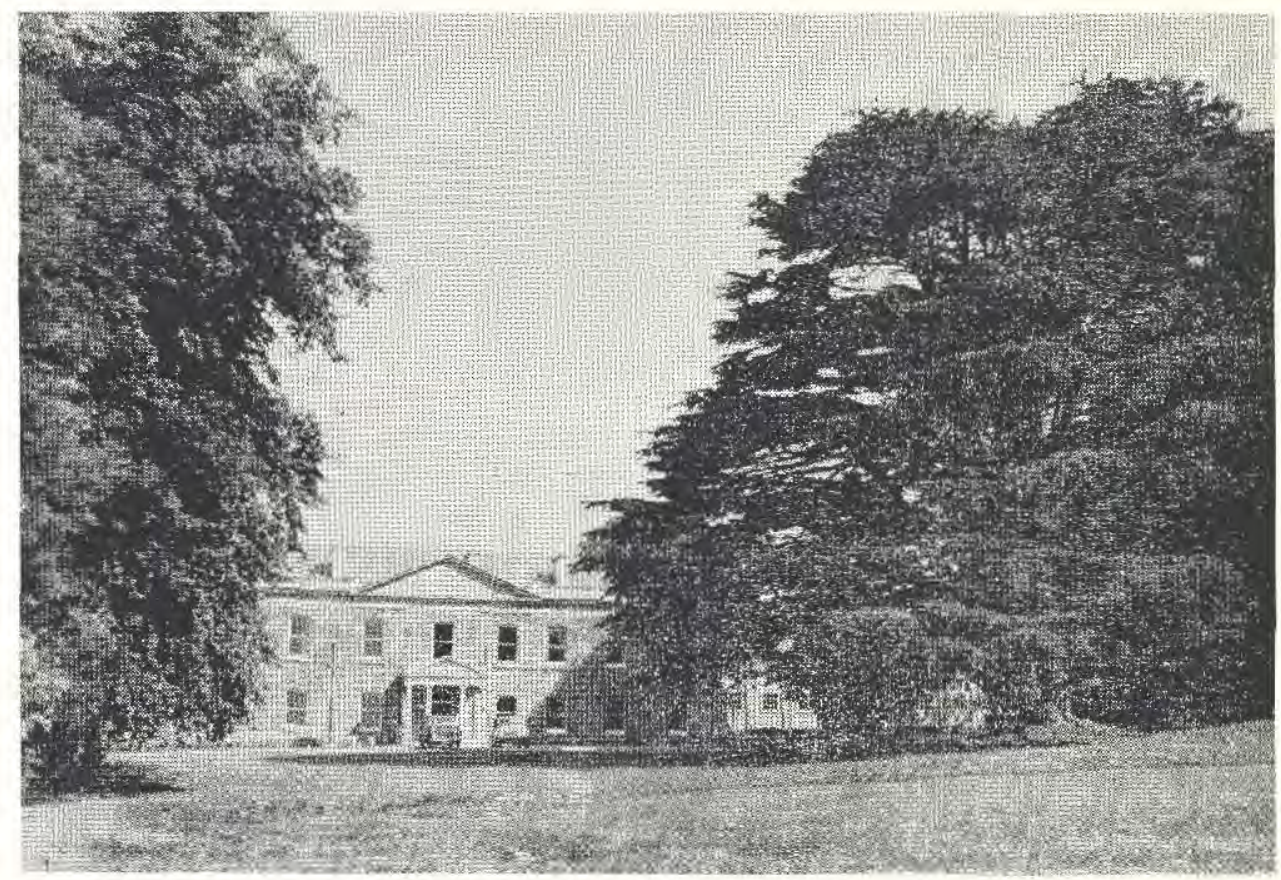

Fig. 1

More directly related to these laboratories, Bruce was a member (1900-1902) of a commission in South Africa which investigated the origins of dysentery in the field and its relation to enteric fever. From 1914 onwards General Bruce was Commandant of the Royal Army Medical College, where he contimued his scientific work as chairman of the War Office Pathological Committee and the Trench Fever Committee, and by investigations into tetanus in military hospitals at home. He retired from the Service in 1919 and became Chairman of the Lister Institute, where he remained until his death in 1931.

In answer to "Why were these Laboratories so named ?", no reply ean better that of Major-General A. Sachs, at that time Director of Pathology, who wrote in the Journal of the Royal Army Medical Corps (1951):

"The work of Bruce was of world-wide interest and of lasting value in bacteriological research, and included work on organisms which are the special concern of the Everleigh establishment: his application of his work to the health of the soldier in peace and war must be an inspiration to all Army pathologists. What finer reasons could be found for honouring David Bruce than by associating his name with the laboratories which are in lineal descent of those at Netley in which he worked and those of the College which he subsequently commanded ?."

\section{The Story of the Unit}

Active immunization against typhoid fever has long been one of the British Army's means of maintaining the health of the soldier. Starting with Sir Almroth Wright's work, begun at the Army Medical School, Netley, in 1896 and continued by him on a larger 
scale in India in 1899, anti-typhoid inoculation continued to form part of the established productive and experimental work of the School and of its successor in London, the Royal Army Medical College, until 1939. Prominent among the many distinguished pathologists, including William Leishman, who participated in this work was David Bruce. It was during his tenure as Commandant of the Royal Army Medical College that simple anti-typhoid vaccine was replaced by the now familiar T.A.B., i.e. typhoid, paratyphoid A and paratyphoid B vaccine, in February 1916.

In 1939, under the threat of war, the decision was taken to move the Vaccine and Serology Departments of the Royal Army Medical College to the country, and on 1st September of that year an advance party moved to Tidworth and established the Emergency Vaccine Laboratory in the Southern Command Laboratory until, at the end of September, its own premises in the Tidworth Military Hospital were ready for occupation. It is of interest to note that at this time, when for the first time the Laboratory achieved complete independence, the hand guiding its destiny, as its first Commanding Officer, was none other than that of Lieutenant-Colonel J. S. K. Boyd, R.A.M.C. (later to become Brigadier Sir John Boyd, O.B.E., M.D., F.R.C.P., F.R.S.). Owing to increase of work, plans were made to move part of the establishment to the Everleigh Manor House, and the Subsidiary Emergency Vaccine Laboratory was opened there on 1st April, 1942. This subsidiary laboratory corresponded with the Serology Department of the present unit. The remainder of the Emergency Vaccine Laboratory completed its move to Everleigh on 25th July, 1942. A prominent part of the work of the unit from early, 1942 was research aimed at the production of an effective vaccine against typhus fever. This was transferred to Frant, near Tunbridge Wells in February, 1945. Production of enteric, plague and cholera vaccines and serological reference work continued throughout the war.

In 1946, the name of the unit was changed to the Army Vaccine Laboratory, and in 1948, after the Army Blood Supply Depot in Bristol closed, its work was expanded by the addition of a Transfusion Department. The work of this department included the production and distribution of anticoagulant solutions, various crystalloid preparations and blood transfusion giving and taking sets. The name "Army Vaccine Laboratory" then ceased to be appropriate, and Army Council Instruction No. 63 of 27th January, 1951, ordered a further change to the present title, the David Bruce Laboratories.

The possible need to mobilize men, fit for active service, in the shortest possible time, has been the stimulus inspiring much of the research in these laboratories. The increasing number of inoculations and the systemic and local reactions following some vaccines have caused concern and led to important refinements in vaccination procedures, while ensuring the full potency of the vaccines concerned. An alcoholised enteric vaccine was adopted by the Army and the Royal Air Force in 1943 with no apparent change in the frequency or severity of the reaction rate. In 1953 a return to conventional heatkilled, phenol-preserved enteric vaccine was made, the organisms on this occasion being suspended in tetanus toxoid (T.A.B.T.). Again no noticeable change occurred in the number and severity of reactions which were still appreciable. A highly skilled "combined operation" between The Wellcome Research Laboratories, the Royal Air Force Institute of Pathology and Tropical Medicine and these Laboratories led, in 1959, to the publication by Barr, Sayers and Stamm of their results using a combined enteric 
and tetanus vaccine given by the intradermal route. Not only were these authors able to show that by this method the protection afforded by the enteric component was as good as when administered subcutaneously, and that the tetanus antitoxin responses were significantly better, but also that the number and severity of both general and local reactions were dramatically decreased.

With the introduction of disposable transfusion apparatus and infusion fluids, and the formation of the Army Blood Supply Depot at Aldershot, the Transfusion Department was closed in 1960. This reduction in the size of the unit was, however, short lived, as from 1961 it has been required to maintain and staff the Southern Command Static Medical Recruiting Display and in 1964 the Civilian Medical Services (now AMD 9), Medical Officer, Radiation, and his staff took up residence at the laboratories.

Following directly from the successful reduction of inoculation reactions when T.A.B.T. vaccine was administered by the intradermal route, it was shown in 1965 that cholera vaccine, given intradermally, was accompanied by a similar reduction in reactions, while the experimental evidence of protection afforded was as good as when it was administered by the subcutaneous route. Intradermal cholera vaccination has since been adopted in the Army as a routine procedure.

Throughout the years these laboratories have not only manufactured vaccines but have also prepared and distributed diagnostic sera and suspensions to Army laboratories throughout the world, and acted as a reference laboratory for enteric, dysentery and cholera organisms. Since 1966 these products have also been made available to Royal Navy and Royal Air Force laboratories and many civilian institutions, with a consequent marked increase in the output of our manufactured products.

The present duties of the unit are:-

(a) To prepare T.A.B.T., T.A.B., Dilute T.A.B. (for children), plague and cholera vaccines, and to issue them, together with poliomyelitis vaccine.

(b) To prepare and issue diagnostic sera and suspensions for use in Service laboratories and also dirofilaria immitis antigen.

(c) To act as a reference laboratory for enteric, dysentery and cholera organisms.

(d) To arrange courses of instruction in these subjects for officers and laboratory technicians of both the Regular Army and the Reserve.

(e) To carry out research work in these and related subjects.

(f) To accomodate the Medical Officer, Radiation, and his staff.

(g) To maintain and staff the Southern Command Static Medical Recruiting Display.

\section{Everleigh and the Manor House}

Everleigh is derived from the Anglo-Saxon words ebor or eofor, a wild boar and ley or leah, a forest glade or meadow; that is " the place of the wild boar ", reminiscent of the time when this part of Wiltshire was in fact dense forest.

The manor belonged to Henry Plantaganet, Earl of Lancaster, in the early fourteenth century. Inherited by marriage by John o'Gaunt, fourth son of Edward III, the manor passed to his son Henry Bolingbroke, later to become King in 1399. It remained in Royal hands until granted to Sir Ralph Sadlier by Queen Elizabeth I in 1560. 
The present manor house is reputed to have been built by Sir Ralph Sadlier, Falconer to Queen Elizabeth I, and at one time charged with the custody of Mary, Queen of Scots. He held the manor of Everleigh from about 1560 until his death in 1587. After passing through several other hands, Sir John Astley, Bart., of Patteshull, Staffordshire, acquired the manor in 1764 . He died without heir, and the property passed to his distant cousin, Francis Dugdale Astley, a descendant of Sir William Dugdale, Garter, the herald and antiquary. In 1821 the baronetcy was recreated in favour of Francis Astley's son and successor, John Dugdale Astley, who extensively remodelled the house. Only the west wing still retains its original character, the interior of the remainder having been destroyed by fire and rebuilt in 1881-2, as commemorated by an inscription over the fireplace in the entrance hall.

The house was bought in 1920 by the National Deposit Friendly Society as a convalescent home. It was commandeered by the War Department at the beginning of the Second World War, and more recently purchased by the Army.

The Astley arms (azure, a cinquefoil pierced ermine) which may be seen carved on the stone pediment over the porch, are so given, with the addition of an ingrailed border, in Fr. John Brackley's Book of Arms (ca 1450).

\section{REFERENCES}

BARR M., SAyers M. H. P., and StAmM W. P. (1959), Lancet, (1), 816.

BRACKLEY, Fr. J. (ca 1450), Book of Arms.

Davm Bruce Laboratories, War Diary.

EDWARDS W. A. (1938), Everleigh-Some Notes on its Story, E. H. Perkins and Sons Ltd.

REPORT OF THE ANTITYPHOID COMMISSION, GREAT BRITAIN (1912), H.M.S.O., London.

RoBertson, Muriel (1955), J. roy. Army med. Corps, 101,91.

SACKS A. (1951), J. roy. Army med. Corps, 97, 293.

Tullouch, W. J. (1955), J. roy. Army med. Corps, 101, 81.

WrLliams H. (1952), The Conquest of Fear, Jonathan Cape, London. 